GRASAS Y ACEITES 69 (1)

January-March 2018, e237

ISSN-L: 0017-3495

https://doi.org/10.3989/gya.0887171

\title{
Evaluation of oil and flour for human nutrition obtained from conventional and organic grape seed Bordô from a winery in the South of Brazil
}

\author{
P.O. Gauer ${ }^{\mathrm{a},} \bowtie$, M.C.A. Silva ${ }^{\mathrm{a}}$ and S. Hoffmann ${ }^{\mathrm{a}}$ \\ ${ }^{a}$ Universidade do Vale do Taquari - Univates - Lajeado (RS), Brazil. \\ ${ }^{\bowtie}$ Corresponding author: pgauer@universo.univates.br
}

Submitted: 27 August 2017; Accepted: 17 November 2017

\begin{abstract}
SUMMARY: The south of Brazil is one of the largest producers of grapes, and as a consequence there is a large generation of waste that can be used as a profitable alternative source. The aim of this work was to obtain and evaluate oil and the flour for human consumption from the residue of cold-pressed Bordô from conventional and organic grape seeds in a winery in the south of Brazil. By cold pressing, the organic oil obtained higher yield. The quality parameters of the conventional oil were better, although with a higher index of peroxides and iodine. The conventional flour presented better results for quality and centesimal composition, mainly due to the higher fiber content and the fact that it did not contain high acidity or humidity. Therefore, the results of products were similar for both crops, but the conventional one was better. However, traces in the agrochemical residue analysis found for the conventional crop might better qualify the organic products.
\end{abstract}

KEYWORDS: Centesimal composition; Flour; Oil; Quality

RESUMEN: Evaluación de aceites y harinas, para nutrición humana, obtenidos de semillas de uvas convencionales y orgánicas Bordô del sur de Brasil. El sur de Brasil es uno de los mayores productores de uva, por lo que existe una gran generación de residuos que se pueden utilizar como fuente alternativa y rentabilizar. El objetivo de este trabajo es obtener y evaluar los aceites y las harinas, para nutrición humana, del residuo de prensado en frío de las semillas de uva convencionales y orgánicas de Bordô en una bodega del sur de Brasil. Al presionar en frío, el aceite orgánico se obtuvo con gran rendimiento. Los parámetros de calidad del aceite convencional fueron mejores, aunque con un mayor índice de peróxidos y de yodo. La harina de semillas convencionales presentó mejores parámetros de calidad y composición centesimal, principalmente debido al mayor contenido en fibra y no tuvieron acidez alta o humedad. Por lo tanto, los resultados de los productos fueron similares para ambos cultivos, pero el convencional fue mejor. Por otro lado, el análisis de trazas de residuos agroquímicos podrían calificar los productos como orgánicos.

PALABRAS CLAVE: Aceite; Calidad; Composición centesimal; Harina

ORCID ID: Gauer PO https://orcid.org/0000-0001-7319-3200, Silva MCA https://orcid.org/0000-0002-1104-8355, Hoffmann S https://orcid.org/0000-0001-5682-4429

Citation/Cómo citar este artículo: Gauer PO, Silva MCA, Hoffmann S. 2108. Evaluation of oil and flour for human nutrition obtained from Bordô from conventional and organic grape seeds in a winery in the South of Brazil. Grasas Aceites 69 (1), e237. https://doi.org/10.3989/gya.0887171

Copyright: (02018 CSIC. This is an open-access article distributed under the terms of the Creative Commons Attribution 4.0 International (CC BY 4.0) License. 


\section{INTRODUCTION}

Southern Brazil represents one of the largest grape producers in the country, with a record crop in 2017 of $750.612 .622 \mathrm{t}$ grapes (Ibravin, 2017). One of the major problems faced by wineries is the waste generation from their productive process, coming from its production process as the crushing and pressing of the grape for wine and juice. These residues are grape marc, consisting mainly of seeds and bark. An alternative for the wineries is the reuse of the residues for the development of products such as oil (Assumpção et al., 2015) and flour from the residue of the cold-pressing of the grape seeds (Özvural and Vural, 2011), generating a source profitability that offers benefits to human health. In addition, the waste can be utilized in food, pharmaceutical or cosmetic industries (Freitas, 2007).

The oil and flour from grape seeds can be used in functional foods since they possess bioactive compounds. Grape-seed oil contains vitamin E (tocopherols), phenolic compounds and lipids (fatty acids) (Assumpção et al., 2015). Linoleic and linolenic acids are considered essential fatty acids because they are not synthesized by the body, and they participate in the transport of oxygen to blood plasma and in the production of hemoglobin (Martin et al., 2006).

The oil can be obtained by cold-pressing, a more interesting method for being a simple practice, suitable for large-scale production. This technique does not involve heat or chemical treatments, nor does it alter the quality of the seed and it can retain more components, without leaving chemical residues as the conventional method of solvent extraction does ( $\mathrm{Yu}$ et al., 2005). However, its yield is lower than from other methods (Vieira et al., 2015).

The flour can be obtained from the residue of the cold-pressing of the seeds by grinding, and it can be a form of reuse for the winery and also present many properties as a source of antioxidants. According to $\mathrm{Yu}$ et al. (2005), antioxidants act in the prevention of aging and of chronic diseases such as the cardiacs and cancer, because they prevent the reactive oxygen species that cause DNA damage and the oxidative reactions performed by free radicals.

An increase in the consumption of organic products stems from the concern on the part of consumers regarding the ingestion of contaminants from conventional cultivation in the form of traces of agrochemicals (Pussemier et al., 2006). According to studies, organic and conventional crops differ in relation to secondary minerals and plant metabolites, but organic cultivation may have lower levels of nitrates (Winter and Davis, 2006).

Grape seed oil may be used for frying because it presents heat stability and contributes a desirable buttery flavor. However, grape seeds present high amounts of unsaturated fatty acids contained in the seed, and therefore it is necessary to verify the oxidative stability (Poiana et al., 2009) of the oil and flour obtained from the cold-press residue of the seeds.

The objective of the present work was to obtain oil by cold pressing the Bordô seeds of conventional and organic cultivation and the flour of the residues resulting from the production of oil, as well as the evaluation of the quality and nutritional content of these products in a winery in the south of Brazil. The winery under study reached a maximum production capacity in this harvest of 2017 with 22000 t of grapes, generating about $20 \%$ of residue consisting of $11 \%$ bark, $3 \%$ seeds and $6 \%$ stalks, which currently are destined for silage (animal feed) or organic fertilization (incorporation into the soil). This case study was developed in line with the company's interest in using this residue to develop new products, as this would be sustainable and profitable, and many companies in the south of Brazil do not have this technology. In addition, oil and flour are considered functional foods, so it is important to ascertain quality and nutritional contents with a focus on omegas and vitamin E (tocopherols). Considering the quantity of seeds generated by the company, about $7-20 \%$ oil can be obtained according to Matthäus (2008), which would represent approximately 46.2-132 t of oil.

\section{MATERIALS AND METHODS}

\subsection{Collection and preparation of material}

Two bagasse samples of $200 \mathrm{~kg}$ were collected (barks and seeds), one from conventional and the other from organic Bordô grapes (Vitis labrusca), both from the 2017 harvest. The samples came from a juice production process of a winery from the Rio Grande do Sul State, Brazil, for the oil extraction. This bagasse was spread onto a flat surface of $15 \mathrm{~m}^{2}$ in a closed room with absolute humidity of approximately $20 \mathrm{~g} / \mathrm{m}^{3}$, without light for initial drying at room temperature of $21^{\circ} \mathrm{C}$ for a period of $24 \mathrm{~h}$ in order to facilitate the separation of the bark and seeds. The separation was carried out with 3 $\mathrm{mm}$ mesh sieves and a blower. The seeds were stored in black plastic bags of $50 \mathrm{~L}$, closed and placed in cardboard boxes and taken to the University laboratory located in Lajeado/RS, where they were kept refrigerated at $5{ }^{\circ} \mathrm{C}$ until moisture analysis and subsequent drying. For the determination of humidity, $30 \mathrm{~g}$ of sample were placed in an air circulation chamber with a temperature of $105^{\circ} \mathrm{C}$ for 3 hours until constant weight, as adapted from the methodology of the Adolfo Lutz Institute (2008). This same methodology was used for seed drying. 


\subsection{Obtaining of seed oil from grapes}

The oils from organic and conventional Bordô grape seeds were extracted after drying, by coldpressing with the Scott Tech ERT 50 screw extruder, which operates with a $1.5 \mathrm{~kW}$ three-phase motor with a processing capacity of $20 \mathrm{~kg} / \mathrm{h}$. This equipment is a continuous system but was used in batch to avoid clogging by placing the whole seeds from 100 into $100 \mathrm{~g}$ to determine the total amount used. The working pressure of the equipment is not reported.

This process was carried out in a food company in the city of Garibaldi-RS. The oil obtained was allowed to decant for 24 hours at room temperature, and the oil and the residual sludge were separated. The oil filtration was performed by gravity after this period, using a sieve with $0.5 \mathrm{~mm}$ mesh to withdraw larger particles and the residual sludge was formed, and stored in closed marked transparent plastic bottles. The oil volume and mass obtained were used for gravimetric yield calculation. This parameter represents the mass amount obtained from the mass of pressed seeds, and it allows for the yield result comparison of each crop, whether organic or conventional. The oil was sent to a certified company for the rendering of services located in the city of Garibaldi-RS, to evaluate the quality of the oil obtained from the seeds of the two types of cultivation, according to $\mathrm{RDC} \mathrm{n}^{\circ}$ 270/2005 and FAO/WHO (2015). The analyses were carried out by a rendering services laboratory located in Garibaldi-RS, as shown in Table 1.

\subsection{The production of flour}

Organic and conventional flour were obtained using the residue of the seeds from cold pressing. An amount of $50 \mathrm{~g}$ of seeds was added during 1 min rotation of $27000 \mathrm{RPM}$ in the Multipurpose Technical User TE-631/1 milling equipment, located in the laboratory of Universidade do Vale do Taquari - UNIVATES with an ambient temperature of $22{ }^{\circ} \mathrm{C}$. This process was repeated 10 times to obtain $500 \mathrm{~g}$ of flour from each culture. The flour was subjected to a 35 -mesh sieve to obtain a fine powder. The flour was packaged in black plastic bags and sent to the same laboratory as mentioned

TABLE 1. Physico-chemical analysis of oil and flour and the methodologies used by the service rendering laboratory located in Garibaldi-RS

\begin{tabular}{|c|c|}
\hline Analysis & Methodology \\
\hline Humidity and volatile substances $^{\circ}$ & Gravimetric \\
\hline Density $^{\circ}$ & Norms IAL, $4^{\mathrm{a} e d .} \mathrm{SP}-2005$, item $215 / \mathrm{IV}$ \\
\hline Refractive index ${ }^{\circ}$ & $\begin{array}{l}\text { AOAC } 921,08,2005 \\
\text { AOAC 993.20, 2005; AOAC } 920.158,2005\end{array}$ \\
\hline Iodine index ${ }^{\circ}$ & $\begin{array}{l}\text { and Compendio Brasileiro de Alimentacao Animal, 2009, } \\
\text { method } 31\end{array}$ \\
\hline Unsaponifiable matter $^{\circ}$ & $\begin{array}{l}\text { AOAC } 933.08,2005 \text { and } \\
\text { Analytical Norms IAL, 2005, item 339/IV }\end{array}$ \\
\hline Acidity index ${ }^{\circ}$ & Norms IAL, $4^{\mathrm{a} e d .} \mathrm{SP}-2005$, item 325/IV \\
\hline Peroxide value $^{\circ}$ & AOAC $965.33,2005$ \\
\hline $\begin{array}{l}\text { Vitamin } E^{\circ} \text { (Levels of Tocopherol: a-tocopherol, } \\
\beta \text { - tocopherol, } \delta \text { - tocopherol and } \gamma \text { - tocopherol) }\end{array}$ & $\begin{array}{l}\text { LC-FLD - EM 12822:201 - Teste carried out in the laboratory of } \\
\text { the Eurofins Group }\end{array}$ \\
\hline $\begin{array}{l}\text { Fatty acid }{ }^{\circ} \text { C4:0;C6:0;C8:0;C10:0; } \\
\text { C12:0;C14:0; C14:1;C16:0;C16:1;C17:0; } \\
\text { C17:1;C18:0; C18:1;C18:2;C18:3;C20:0; } \\
\text { C20:1;C22:0;C22:2;C22:1;C24:0;C24:1) }\end{array}$ & 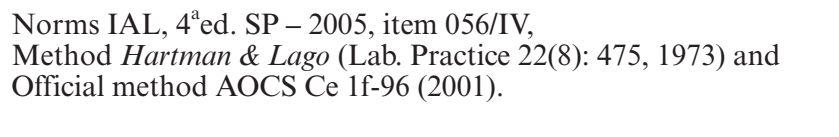 \\
\hline Humidity ${ }^{\mathrm{F}}$ & Gravimetric \\
\hline Acidity index ${ }^{\mathrm{F}}$ & Norms IAL, $4^{\mathrm{a} e d .}$ SP -2005 , item 016/IV \\
\hline Total fat ${ }^{\mathrm{F}}$ & AOAC 922.06, 2005; AOAC 935.39, 2005. \\
\hline Total food fiber ${ }^{\mathrm{F}}$ & $\begin{array}{l}\text { AOAC INTERNATIONAL. Total, Soluble and Insoluble Dietary } \\
\text { Fiber in Foods: Method } 991.43\end{array}$ \\
\hline Fixed mineral residue ${ }^{\mathrm{F}}$ & Norms IAL, $4^{\mathrm{a}} \mathrm{ed} . \mathrm{SP}-2005$, item 018/IV \\
\hline Carbohidrates $^{\mathrm{F}}$ & $\mathrm{RDC} \mathrm{n}^{\circ} 360$ de 23/12/2003 - ANVISA \\
\hline $\operatorname{Protein}^{\mathrm{F}}(\mathrm{N} \times 5,75)$ & $\begin{array}{l}\text { Kjeldhal - PNT24-AL - } \\
\text { Procedure for determination of total protein }\end{array}$ \\
\hline $\begin{array}{l}\text { Vitamin } E^{\mathrm{F}} \text { (Perfil Tocopherol: } \\
\text { a-tocopherol, } \beta \text { - tocopherol, } \delta \text { - tocopherol e } \gamma \text { - tocopherol) }\end{array}$ & $\begin{array}{l}\text { LC-FLD - EN 12822:201 - Test carried out in a laboratory of the } \\
\text { Eurofins group }\end{array}$ \\
\hline
\end{tabular}

${ }^{\circ}$ Oil analysis, ${ }^{\mathrm{F}}$ Flour analysis 
above for quality analysis and centesimal composition, as shown in Table 1.

The moisture analysis of the flour resulted in a percentage in $\mathrm{g} / 100 \mathrm{~g}$, according to RDC $\mathrm{n}^{\circ}$ $263 / 2005$. For acidity comparison, there is no legislation regulating values, but the analysis was carried out to guarantee the quality regarding rancidity due to the presence of residual oil. The other analyses were performed to satisfy the Brazilian legislation for labels, which cites the nutrients present, but does not quantify values, according to $\mathrm{RDC} \mathrm{n}^{\circ} 360 / 2003$.

\section{RESULTS AND DISCUSSIONS}

\subsection{Moisture analysis and seed drying}

The seed moisture analysis was performed to determine the water content present after the preliminary drying of the bagasse in the company under study. This is an important parameter to verify the possible occurrence of hydrolytic rancidity. The seeds were dried for oil and flour production. The results of the moisture analysis and the standard deviation of moisture are reported in Table 2.

Brazilian legislation does not specify a moisture value for seeds to be used for oil extraction. According to the study by Bruni et al., (2014), Chardonnay seeds of Bagé-RS were dried at 40, 60 and $80{ }^{\circ} \mathrm{C}$, with the averages for moistureon wet basis of approximately $43 \%, 43 \%$ and $42 \%$, respectively. The results presented in this study are close to those found by Bruni et al., (2014).

The preliminary seed drying was carried out on different days. Therefore, the moisture difference between the two crops can be justified by the atmospheric conditions, as the air relative humidity equilibrates with the moisture of the seeds.

\subsection{Oils results}

\subsubsection{Cold pressing extraction performance}

The organic grape oil was obtained by using $30 \mathrm{~kg}$ of seeds for 1 liter of oil, representing a yield of $3.50 \%$. The conventional oil was produced using approximately $41 \mathrm{~kg}$ of seeds to obtain 1L of oil, representing $2.44 \%$. This variation in yield between the crops depends on the variety, degree of grape maturation, environmental factors, mode of preparation of the seeds before extraction, extraction method and mode of extraction (Fiori et al., 2014).

According to the method of Vieira et al., (2015), the yield obtained from the grape Bordô without specification of the cultivar by the cold pressing method, with drying of the seeds at $40{ }^{\circ} \mathrm{C}$ and 80 ${ }^{\circ} \mathrm{C}$, respectively, presented 8 and $4 \%$ of oil. The difference in oil quantity between the two crops was clear, and there was a considerable variation when comparing the study by Vieira et al., (2015).

\subsubsection{Oil quality analyses}

The results of the oil quality analyses are shown in Table 3.

Moisture in the oil. The results obtained for moisture were $0.352 \%$ for the organic oil and $0.159 \%$ for the conventional one, as shown in Table 3. It was verified that the value for the organic oil was above the permitted level and this could lead to deterioration (hydrolytic rancidity).

TABLE 2. Results of moisture analysis and the standard deviation (triplicate) in Grape Seeds

\begin{tabular}{lcccc}
\hline & Humid sample Mean (g) & Humidity loss $(\mathrm{g})$ & Standard deviation & Humidity $(\%)$ \\
\hline Bordô organic grape seed & 29,99 & 11,37 & 0,13 & 37,93 \\
Bordô conventional grape seed & 30.00 & 6,80 & 0,02 & 22,68
\end{tabular}

TABLE 3. Results of the quality analyses of organic and conventional oil according to the parameters of FAO/WHO (2015) and $\mathrm{RDC} \mathrm{n}^{\circ} 270 / 2005$

\begin{tabular}{lcccc}
\hline Analysis & FAO/WHO (2015) & RDC n $^{\circ} \mathbf{2 7 0}$ (ANVISA. 2005) & Organic oil result & Conventional oil result \\
\hline $\begin{array}{l}\text { Humidity and volatile } \\
\text { substances }\end{array}$ & $0.20 \%$ & - & $0.35 \%$ & $0.16 \%$ \\
Density & $0.920 \mathrm{a} 0.926 \mathrm{~g} / \mathrm{mL}$ & - & $0.921 \mathrm{~g} / \mathrm{mL}$ & $0.926 \mathrm{~g} / \mathrm{mL}$ \\
Refractive index & $1.467 \mathrm{a} 1.477$ & - & 1.474 & 1.4738 \\
Peroxide value & Maximum $15 \mathrm{meq} / \mathrm{Kg}$ & Maximum $15 \mathrm{meq} / \mathrm{Kg}$ & $9.1 \mathrm{meq} / \mathrm{Kg}$ & $9.22 \mathrm{meq} / \mathrm{Kg}$ \\
Acidity index & Maximum $4.0 \mathrm{mg} \mathrm{KOH} / \mathrm{g}$ & Maximum $4.0 \mathrm{mg} \mathrm{KOH} / \mathrm{g}$ & $6.33 \mathrm{mg} \mathrm{KOH} / \mathrm{g}$ & $5.81 \mathrm{mg} \mathrm{KOH} / \mathrm{g}$ \\
Iodine index & $128 \mathrm{a} 150 \mathrm{~g} \mathrm{I} / 100 \mathrm{~g}$ & - & $134 \mathrm{~g} \mathrm{I} / 100 \mathrm{~g}$ & $138 \mathrm{~g} \mathrm{I} / 100 \mathrm{~g}$ \\
Unsaponifiable matter & $\leq 20 \mathrm{~g} / \mathrm{Kg}$ & - & $7.35 \mathrm{~g} / \mathrm{Kg}$ & $9.33 \mathrm{~g} / \mathrm{Kg}$ \\
\hline
\end{tabular}


Differences in moisture values may occur due to variations in the conditions of the exposed environment, since the oils were extracted at the food company on different days and decanted at different locations. Decantation of the organic oil was done at the food company where it was extracted and the conventional oil was decanted in the laboratory of the cellar under study, both over 24 hours. The variation can also be the result of the extraction process because heat $\left(59^{\circ} \mathrm{C}\right)$ is generated with the friction of the seeds, which could cause condensation in the equipment, adding water to the product. After decantation, the two oils were sent to the laboratory for analysis.

Density. The results of oil density or specific mass were $0.921 \mathrm{~g} / \mathrm{mL}$ for the organic oil and $0.926 \mathrm{~g} / \mathrm{mL}$ for the conventional oil. According to the Codex Alimentarius (FAO/WHO, 2015), the maximum permitted value is 0.920 to $0.926 \mathrm{~g} / \mathrm{ml}$; the values are within the indicated range, but it can be observed that the conventional oil had the highest density.

Oil refractive index. The refractive index, as presented in Table 3, for conventional and organic oils, presented values within the FAO/WHO specification (1.467 to 1.477 ) (2015) with values of 1.473 and 1.474 , respectively. Regarding the cultivations, a small variation was noted, so it can be affirmed that both had approximately the same refractive index.

Peroxide index. According to FAO/WHO (2015) and RDC $\mathrm{n}^{\circ} 270 / 2005$, the peroxide index should be maximum $15 \mathrm{meq} / \mathrm{kg}$ for cold and virgin pressed oils. The results of the oils are in agreement with the established limits, with values of $9.1 \mathrm{meq} / \mathrm{kg}$ for organic oil and $9.2 \mathrm{meq} / \mathrm{kg}$ for the conventional oil. The conventional oil showed the highest degree of oxidation.

Acidity index. In this study, the acid index result was $6.33 \mathrm{mg} \mathrm{KOH} / \mathrm{g}$ for organic grape oil Bordô and $5.81 \mathrm{mg} \mathrm{KOH} / \mathrm{g}$ for the conventional one. According to FAO/WHO (2015) and RDC n ${ }^{\circ}$ $270 / 2005$, the acid value is at most $4.0 \mathrm{mg} \mathrm{KOH} / \mathrm{g}$, so the two oils are above the parameters, indicating that there is hydrolytic rancidity, with the largest for organic oil.

Iodine index. According to FAO/WHO (2015), the iodine index for grape oil should be 128 to 150 $\mathrm{g} \mathrm{I}_{2} / 100 \mathrm{~g}$. In the analysis, the organic grape oil had a value of $134 \mathrm{~g} \mathrm{I}_{2} / 100 \mathrm{~g}$ and the conventional oil showed $138 \mathrm{~g} \mathrm{I}_{2} / 100 \mathrm{~g}$, within the specified range. It was verified that the conventional oil had a higher iodine index. This result can attribute to higher unsaturation and high oxygen reaction susceptibility, favoring the occurrence of oxidative rancidity.

Unsaponifiable matter. In the verification of the unsaponifiable matter, both oils were within the value established by the FAO/WHO (2015) standard, with values of $9.33 \mathrm{~g} / \mathrm{kg}$ for the conventional and $7.35 \mathrm{~g} / \mathrm{kg}$ for the organic oil. This result is satisfactory as it means that the products are within the standards of identity and quality for grape seed as established by FAO/WHO (2015). Therefore, the product will have the established color (pigments) and odor (aliphatic alcohols) parameters (Instituto Adolfo Lutz, 2008).

Vitamin $\boldsymbol{E}$. Regarding the determination of vitamin E, the data are shown in Table 4. According to Table 4, the results of alpha-tocopherol, deltatocopherol and gamma-tocopherol presented values above the table by FAO/WHO (2015), for organic as well as for conventional oil. According to Mustacich et al., (2009), this excess in tocopherol does not harm the health, because in its study in rats, it was verified that the liver alters the functions of secretion allowing the release of vitamin $\mathrm{E}$, thus regulating the rate in the body and does not cause harm.

According to Silva et al., (2006), the amount of vitamin $\mathrm{E}$ in fruits can vary with the species, maturation, genetic changes, storage and processing.

Determination of fatty acids. The results of the fatty acid analyses were compared with the FAO/ WHO (2015) parameters, which are presented in Table 5.

According to the results, the fatty acid levels in the organic and conventional oil were within the FAO/WHO (2015) tabulated parameters. According to Table 5, variations were observed in relation to the cultivations, being that the organic oil presented higher contents of palmitic acid (C 16:0), palmitoleic (C 16:1), stearic (C 18:0), oleic (C 18:1) and linolenic acid (C 18:3); whereas the conventional one had higher values for linoleic acid (C 18:2) and eicosanoic acid (C 20:1).

\subsubsection{Organic versus conventional cultivation of Bordô grape seed oil}

As for quality parameters, variations were observed for organic cultivation, and the values for moisture and acidity index were higher. For the conventional oil, the values for peroxide index and iodine index were higher when compared to the organic oil. When analyzing vitamin E for both cultivations, the results were above that specified by the

TABLE 4. Results obtained from vitamin E analysis of organic and conventional oil

\begin{tabular}{lccc}
\hline $\begin{array}{l}\text { Vitamin E } \\
\text { (levels of }\end{array}$ & FAO/WHO & \multicolumn{2}{c}{ Grape seed oil (mg/kg) } \\
\cline { 3 - 4 } tocopherols) & $\begin{array}{c}(\mathbf{2 0 1 5}) \\
(\mathbf{m g} / \mathbf{k g})\end{array}$ & $\begin{array}{c}\text { Organic } \\
\text { oil }\end{array}$ & $\begin{array}{c}\text { Conventional } \\
\text { oil }\end{array}$ \\
\hline$\alpha$-tocopherol & $16.0-38.0$ & 203 & 219 \\
$\beta$-tocopherol & $\mathrm{ND}^{\mathrm{a}}-89.0$ & 13.5 & 14.7 \\
$\delta$-tocopherol & $\mathrm{ND}^{\mathrm{a}}-4.0$ & 30.1 & 42.3 \\
$\gamma$-tocopherol & $\mathrm{ND}^{\mathrm{a}}-73.0$ & 117 & 219 \\
\hline
\end{tabular}

${ }^{\mathrm{a}}$ Non detectable 
TABLE 5. Results obtained from fatty acid analysis of organic and conventional oils

\begin{tabular}{|c|c|c|c|}
\hline \multirow[b]{2}{*}{ Fatty acid } & \multirow[b]{2}{*}{ FAO/WHO (2015) (\%) } & \multicolumn{2}{|c|}{ Grape seed oil } \\
\hline & & Organic oil( $(\%)$ & Conventional oil(\%) \\
\hline Caproic acid - C 6:0 & $\mathrm{ND}^{\mathrm{a}}$ & $<0.10$ & $<0.10$ \\
\hline Caprylic acid - C 8:0 & $\mathrm{ND}^{\mathrm{a}}$ & $<0.10$ & $<0.10$ \\
\hline Capric acid - C 10:0 & $\mathrm{ND}^{\mathrm{a}}$ & $<0.10$ & $<0.10$ \\
\hline Lauric acid - C 12:0 & $\mathrm{ND}^{\mathrm{a}}$ & $<0.10$ & $<0.10$ \\
\hline Myristic acid - C 14:0 & $\mathrm{ND}^{\mathrm{a}}-0.30$ & $<0.10$ & $<0.10$ \\
\hline Palmitic acid - C 16:0 & $5.5-11.00$ & 6.83 & 6.41 \\
\hline Palmitoleic acid - C 16:1 & $\mathrm{ND}^{\mathrm{a}}-1.20$ & 0.15 & 0.12 \\
\hline Heptadecanoic acid - C 17:0 & $\mathrm{ND}^{\mathrm{a}}-0.20$ & $<0.10$ & $<0.10$ \\
\hline Cis-10-Heptadecanoic acid - C 17:1 & $\mathrm{ND}^{\mathrm{a}}-0.10$ & $<0.10$ & $<0.10$ \\
\hline Stearic acid - C 18:0 & $3.00-6.50$ & 3.67 & 3.4 \\
\hline Oleic acid - C 18:1 & $12.00-28.00$ & 20.7 & 18.91 \\
\hline Linoleic acid - C 18:2 & $58.00-78.00$ & 62.81 & 65.34 \\
\hline Linolenic acid - C 18:3 & $\mathrm{ND}^{\mathrm{a}}-1.00$ & 0.4 & 0.39 \\
\hline Arachidic acid - C 20:0 & $\mathrm{ND}^{\mathrm{a}}-1.00$ & 0.19 & 0.19 \\
\hline Eicosanoic acid - C 20:1 & $\mathrm{ND}^{\mathrm{a}}-0.30$ & 0.17 & 0.18 \\
\hline Behenic acid - C 22:0 & $\mathrm{ND}^{\mathrm{a}}-0.50$ & $<0.10$ & $<0.10$ \\
\hline Cis-13.16-Docosadienoic acid - C 22:2 & $\mathrm{ND}^{\mathrm{a}}$ & $<0.10$ & $<0.10$ \\
\hline Erucid acid - C 22:1 & $\mathrm{ND}^{\mathrm{a}}-0.30$ & $<0.10$ & $<0.10$ \\
\hline Lignoceric acid - C 24:0 & $\mathrm{ND}^{\mathrm{a}}-0.40$ & $<0.10$ & $<0.10$ \\
\hline Nervonic acid - C 24:1 & $\mathrm{ND}^{\mathrm{a}}$ & $<0.10$ & $<0.10$ \\
\hline
\end{tabular}

${ }^{a}$ Non detectable, defined as $\leq 0.05 \%$

FAO/WHO (2015). The fatty acid analyses results were in agreement with the legislation for both cultivations; the linolenic and eicosanoic acids were higher in the conventional oil; whereas palmitic, palmitoleic, stearic, oleic and linoleic acids had higher concentrations in the organic oil. In general, the conventional oil presented better results and differences were verified between the cultivations regarding quality analyses.

\subsection{Results of the flour obtained from the residue of cold pressed seeds}

\subsubsection{Flour quality analysis}

The results from the analysis of the flour obtained from the residue of cold pressed seeds of both cultivations are presented in Table 6.

According to $\mathrm{RDC} \mathrm{n}^{\circ} 263 / 2005$ the maximum moisture parameter should be $15 \%$, therefore the samples were in compliance with the legislation, emphasizing that the organic cultivation had the highest value. The difference in moisture between the flour of the two cultivations can be explained by the possible aggregation of moisture during handling and preparation.

As mentioned in the methodology, there is no legislation that limits acidity values. This analysis was performed only to verify the quality of the flour, as there may be rancidity due to the presence of residual oil. According to the acidity analysis of the flour, the organic cultivation showed $8.67 \mathrm{mg} \mathrm{KOH} / \mathrm{g}$ and the conventional cultivation showed $7.36 \mathrm{mg}$ $\mathrm{KOH} / \mathrm{g}$. Comparing the results, the organic flour had a higher acidity index which may be related to the higher moisture content or to characteristics of the cultivation.

\subsubsection{Analysis of the centesimal composition of flours}

As mentioned in the methodology, RDC $\mathrm{n}^{\circ}$ $360 / 2003$ cites the necessary nutrients in a label but does not present parameters for the analyses, so the discussion for the flour will not be compared with standard values. The results obtained are described in Table 6.

Total Fat. For the total fat, $1.72 \%$ and $7.05 \%$ were obtained for organic and conventional flour, respectively. This variation in fat between the cultures may be related to the residual oil of the seed pressing. This higher total fat value may favor lipid rancidity, and therefore it can be degraded more easily (Moretto and Fett, 1998).

The ideal oil quality is one that is reduced in fat so as not to be degraded easily. Regarding the 
TABLE 6. Results on humid basis of analysis of the centesimal composition and quality of flour obtained from the residue of cold pressing of grape seeds

\begin{tabular}{|c|c|c|c|c|}
\hline \multicolumn{2}{|l|}{ Analysis } & Legislation & Organic flour & Conventional flour \\
\hline \multicolumn{2}{|l|}{ Humidity } & $\mathrm{RDC}^{\circ}{ }^{\circ} 263 / 2005$ : Maximum 15\% & $6.73 \%$ & $3.68 \%$ \\
\hline \multicolumn{2}{|c|}{ Acidity index } & - & $8.67 \mathrm{mg} \mathrm{KOH} / \mathrm{g}$ & $7.36 \mathrm{mg} \mathrm{KOH} / \mathrm{g}$ \\
\hline \multicolumn{2}{|c|}{ Total fat } & - & $1.72 \%$ & $7.05 \%$ \\
\hline \multicolumn{2}{|c|}{ Total food fiber } & - & $62.70 \%$ & $69.70 \%$ \\
\hline \multicolumn{2}{|c|}{ Ashes } & - & $2.33 \%$ & $2.13 \%$ \\
\hline \multicolumn{2}{|c|}{ Carbohydrates } & - & $17.80 \%$ & $8.29 \%$ \\
\hline \multicolumn{2}{|c|}{ Total protein } & - & $8.71 \%$ & $9.17 \%$ \\
\hline \multirow[t]{4}{*}{ Vitamin E } & $\alpha$-tocopherol & - & $2.17 \mathrm{mg} / 100 \mathrm{~g}$ & $2.05 \mathrm{mg} / 100 \mathrm{~g}$ \\
\hline & $\beta$-tocopherol & - & $<0.50 \mathrm{mg} / 100 \mathrm{~g}$ & $<0.50 \mathrm{mg} / 100 \mathrm{~g}$ \\
\hline & $\delta$-tocopherol & - & $<0.50 \mathrm{mg} / 100 \mathrm{~g}$ & $<0.50 \mathrm{mg} / 100 \mathrm{~g}$ \\
\hline & $\gamma$-tocopherol & - & $1.84 \mathrm{mg} / 100 \mathrm{~g}$ & $2.07 \mathrm{mg} / 100 \mathrm{~g}$ \\
\hline
\end{tabular}

results, conventional flour had more total fat and can be more easily degraded.

A measurement of $5 \mathrm{~g}$ (one tablespoon) of conventional grape flour corresponded to $0.35 \mathrm{~g}$ of total fats. The recommended daily supply of total fat, according to RDC $\mathrm{n}^{\circ} 360 / 2003$, is $55 \mathrm{~g} / \mathrm{d}$, and this measurement of conventional grape flour was equal to $0.64 \%$ of daily requirements. The organic seed flour corresponded to $0.16 \%$ of the daily recommendation.

Total food fiber. With the analysis of total dietary fiber content of the Bordo grape flour, $62.70 \%$ was found for organic flour and $69.70 \%$ for conventional. According to RDC n $\mathrm{n}^{\circ} 54 / 2012$, if the fiber content is higher than $6 \%$, the product is rich in fiber. Therefore, it can be included in the labeling of the flour that they are rich in fiber.

In $5 \mathrm{~g}$ of flour from organic and conventional Bordô grapes $12.5 \%$ and $13.9 \%$ of the recommended daily supply of total food fiber were found, respectively, which is $25 \mathrm{~g} / \mathrm{d}$ (RDC 360/2003).

Protein. The organic Bordô grape flour presented $8.71 \%$ of the protein content (conversion factor of 5.75 - N proteic) and $9.17 \%$ for the conventional flour. Regarding the results, the conventional one presented the greatest amount of protein, excellent for human health.

The recommended daily supply of protein is $75 \mathrm{~g} / \mathrm{d}\left(\mathrm{RDC} \mathrm{n}^{\circ} 360 / 2003\right)$, and the flour of organic and conventional Bordô grapes contained, respectively, $0.58 \%$ and $0.61 \%$ of the daily supply in $5 \mathrm{~g}$.

Carbohydrates. In the carbohydrate quantification, $17.80 \%$ of organic flour and $8.29 \%$ of conventional flour were obtained, presenting a great difference between the cultivations., The recommended daily supply of protein is $300 \mathrm{~g} / \mathrm{d}\left(\mathrm{RDC} \mathrm{n}^{\circ}\right.$ $360 / 2003$ ), and the flour from organic and conventional Bordô grapes contained, respectively, 0.3\% and $0.14 \%$ of the daily supply in $5 \mathrm{~g}$.
Ash. For the ash result, 2.33 and $2.13 \%$ were found for the organic and conventional Bordô flour, respectively, resulting in a small variation.

Vitamin E. The tocopherol profile was analyzed for the quantification of vitamin E. $\alpha$-tocopherol had the highest concentration when compared to the others in the profile. Comparing conventional and organic seed flours, the variation is minimal, which can be justified due to species, maturation, genetic changes, storage and processing (Silva et al., 2006). Absorbed vitamin $\mathrm{E}$ is taken up by the liver, and therefore only $\alpha$-tocopherol is preferentially secreted into low-density lipoprotein (LDL).

\subsubsection{Organic versus conventional cultivation for flour}

Regarding the quality analysis, the organic flour presented higher amounts of moisture and acidity, which may be indicative of rancidity (hydrolytic). Thus, the flour from conventional cultivation presented the best quality results. Analyzing the results of the analysis of centesimal composition according to $\mathrm{RDC} \mathrm{n}^{\circ} 360 / 2003$, the organic flour had a higher carbohydrate content and vitamin $\mathrm{E}$ ( $\alpha$-tocopherol). However, the conventional cultivation flour had the best results for total (more easily degraded) fat, fiber and protein. In general, conventional flour is best for having a higher amount of fiber and not exhibiting high moisture or acidity. Difference existed between the cultures regarding the analysis of quality and centesimal composition.

\subsection{Nutritional comparison of oils and flours}

According to the fatty acid analysis of oils, the $\alpha$-linolenic acid content (omega-3) presented in Table 5 for organic and conventional oil is $0.40 \%$ and $0.39 \%$. According to RDC n ${ }^{\circ} 54 / 2012$, if the 
omega- 3 content presents a value greater than $0.3 \%$, the product can be considered a source of omega-3. Linoleic acid (omega-6) was present at 62.81\% and $65.34 \%$ for conventional and organic oil, respectively, and this product can be claimed high in omega- 6 content in the labeling because it is above $3 \%$ according to $\mathrm{RDC} \mathrm{n}^{\circ} 54 / 2012$.

The daily recommended supply of vitamin $\mathrm{E}$ is $10 \mathrm{mg} / \mathrm{d}\left(\mathrm{RDC} \mathrm{n} \mathrm{n}^{\circ} 360 / 2003\right)$ and the organic and conventional grape flour contained, respectively, 1.08 and $1.02 \%$ of the daily supply. For the calculation of the daily supply, only $\alpha$-tocopherol values were used because this is the main vitamin E compound absorbed by the organism (Otten et al., 2006). Analyzing the results presented in Tables 5 and 8, it can be stated that the composition of tocopherols (vitamin $\mathrm{E}$ ) of the oil presents about 8 times more than in the flour. Regarding the crops, the oil and the flour obtained from conventional cultivation presented more tocopherols.

With these results, it is important to use residuals from the wineries to develop products that bring benefits to human nutrition, especially highlighting these bioactive compounds of omegas and vitamin $\mathrm{E}$ (tocopherols). However, in these analyses the oil was highlighted as a source of omega-3 and 6 . Vitamin E was present in greater quantity in the oil than in the flour.

\section{CONCLUSION}

It was observed that the seed pre-drying process must be carried out on the same day or in a controlled environment to avoid differences in the quality results. The cold pressing technique presented a yield variation between the crops, with the organic one of greater value. The products obtained from the conventional culture seeds presented the best results. In general, the results of oil and flour were similar, but the conventional one is of better quality and centesimal composition. In relation to the contents of omega-3 and 6 and Vitamin E (tocopherols), the oil was more nutritious for human health than the flour. Therefore, the use of seeds to obtain oil and flour is an alternative in the development of products. One suggestion for future work would be to check traces of agrochemicals that could qualify the organic product as better.

\section{REFERENCES}

Agência Nacional de Vigilância Sanitária - Anvisa. 2003. RDC $\mathrm{n}^{\circ} 360$, de 23 de dezembro de 2003. Regulamento Técnico sobre Rotulagem Nutricional de Alimentos Embalados. D.O.U. - Diário Oficial da União, Poder Executivo.

Agência Nacional de Vigilância Sanitária - Anvisa. 2005. RDC $\mathrm{n}^{\circ} 263$, de 22 de setembro de 2005. Regulamento Técnico para Produtos de Cereais, Amidos, Farinhas e Farelos. D.O.U. - Diário Oficial da União, Poder Executivo.

Agência Nacional de Vigilância Sanitária - Anvisa. 2005. RDC $\mathrm{n}^{\mathrm{o}} 270$, de 22 de setembro de 2005. Regulamento Técnico para Óleos Vegetais, Gorduras Vegetais e Creme Vegetal. D.O.U. - Diário Oficial da União, Poder Executivo.

Agência Nacional de Vigilância Sanitária - Anvisa. 2012. RDC $\mathrm{n}^{\circ} 54$, de 12 de novembro de 2012. Regulamento Técnico sobre a Informação Nutricional Complementar. D.O.U. Diário Oficial da União, Poder Executivo.

Assumpção CF, Nunes IL, Mendonça TA, Bortolin RC, Jablonski A, Flôres SH, Rios AO. 2015. Bioactive compounds and stability of organic and conventional Vitis labrusca grape seed oils. J. Am. Oil Chem. Soc. 93, 115-124. https://doi.org/10.1007/s11746-015-2742-0

Bruni GP, Oliveira FM, Crexi VT, Rosa GS, Oliveira EG. 2014. Secagem convectiva de sementes de uva: Influência no conteúdo de óleo extraído. In: XX Congresso Brasileiro de Engenharia Química - COBEQ, 2014, Florianópolis, Santa Catarina. Anais...Florianópolis: Universidade Federal do Pampa, 2014. https://doi.org/10.5151/ chemeng-cobeq2014-0723-24290-180092

Codex Alimentarius International Food Standards - FAO/ WHO. 2015. Standard for Named Vegetable Oils Codex Stan 210-1999. Adopted in 1999. Revision: 2001, 2003, 2009. Amendment: 2005, 2011, 2013 and 2015.

Fiori L, Lavelli V, Duba KS, Harsha PSCS, Mohamed HB, Guella G. 2014. Supercritical CO2 extraction of oil from seeds of six grape cultivars: Modeling of mass transfer kinetics and evaluation of lipid profiles and tocol contents. J. Supercrit. Fluid. 94, 71-80. https://doi.org/10.1016/j. supflu.2014.06.021

Freitas LS. 2007. Desenvolvimento de Procedimentos de Extração do Óleo de Semente de Uva e Caracterização Química dos Compostos Extraídos, PhD Thesis, Instituto de Química, Universidade Federal do Rio Grande do Sul, Brazil.

Instituto Adolfo Lutz. 2008. Métodos físico-químicos para análise de alimentos. 4. Ed. Instituto Adolfo Lutz: São Paulo.

Instituto brasileiro do vinho- IBRAVIN. 2017. Safra de uva 2017 é recorde no Rio Grande do Sul. http://www.ibravin. org.br/Noticia/safra-de-uva-2017-e-recorde-no-rio-grandedo-sul/281

Kim H, Bartley GE, Arvik T, Lipson R, Nah SY, Seo K, Yokoyama W. 2014. Dietary supplementation of chardonnay grape seed flour reduces plasma cholesterol concentration, hepatic steatosis, and abdominal fat content in high-fat diet-induced obese hamsters. J. Agric. Food Chem. 62, 1919-1925. https://doi.org/10.1021/jf404832s

Martin CA, Almeida VV, Ruiz MR, Visentainer JEL, Matshushita M, Souza NE, Visentainer JV. 2006. Ácidos graxos poliinsaturados ômega-3 e ômega-6: importância e ocorrência em alimentos. Rev. Nutr. 19, 761-770. https:// doi.org/10.1590/S1415-52732006000600011

Matthäus B. 2008. Virgin grape seed oil: Is it really a nutritional highlight?. Eur. J. Lipid Sci. Technol. 110, 645-650. https:// doi.org/10.1002/ejlt.200700276

Moretto E, Fett R. 1998. Tecnologia de óleos e gorduras vegetais. Varela, São Paulo.

Mustacich DJ, Gohil K, Bruno RS, Yan M, Leonard SW, Ho E, Cross CE, Traber MG. 2009. Alpha-tocopherol modulates genes involved in hepatic xenobiotic pathways in mice. $J$. Nutr. Biochem. 20, 469-476. https://doi.org/10.1016/j. jnutbio.2008.05.007

Otten JJ, Hellwig JP, Meyers LD. 2006. Dietary reference intakes: the essential guide to nutrient requirements. National Academies Press, Washington.

Özvural EB, Vural H. 2011. Grape seed flour is a viable ingredient to improve the nutritional profile and reduce lipid oxidation of frankfurters. Meat Sci. 88, 179-183. https://doi. org/10.1016/j.meatsci.2010.12.022

Poiana M-A, Jianu C, Jianu I, Rinovetz A. 2009. The storage conditions impact on the oxidative stability and antioxidant properties of grape seed oil. JFAE. 7, 50-53.

Pussemier L, Larondelle Y, Van Peteghem C, Huyghebaert A. 2006. Chemical safety of conventionally and organically produced foodstuffs: a tentative comparison under Belgian conditions. Food Control 17, 14-21.

Ribeiro EP, Seravalli EAG. 2004. Química de alimentos. Edgard Blücler, São Paulo. 
Silva PT, Lopes MLM, Mesquita VLV. 2006. Efeito de diferentes processamentos sobre o teor de ácido ascórbico em suco de laranja utilizado na elaboração de bolo, pudim e geléia. Food Sci. Technol. 26, 678-682. https://doi.org/10.1590/ S0101-20612006000300030

Vieira DS, Menezes M, Gonçalves G, Mukai H, Lenzi EK, Pereira NC, Fernandes PRG. 2015. Temperature dependence of refractive index and of electrical impedance of grape seed (Vitis vinifera, Vitis labrusca) oils extracted by Soxhlet and mechanical pressing. Grasas Aceites 66, e083. https://doi.org/10.3989/gya.0954142

Yu LL, Zhou KK, Parry J. 2005. Antioxidant properties of coldpressed black caraway, carrot, cranberry, and hemp seed oils. Food Chem. 91, 723-729. https://doi.org/10.1016/j. foodchem.2004.06.044

Winter CK, Davis SF. 2006. Organic Foods. J. Food Sci. 71, 117-124. https://doi.org/10.1111/j.1750-3841.2006. 00196.x 